\title{
Clinical and biochemical evaluation of the saliva of patients with xerostomia induced by radiotherapy
}

\section{Avaliação clínica e bioquímica da saliva de pacientes com xerostomia induzida por radioterapia}

\author{
Cássio de Barros Pontes* \\ Ana Cristina Morseli Polizello** \\ Augusto César Cropanese Spadaro***
}

\begin{abstract}
Clinical aspects and biochemical properties in the saliva of 21 patients prior to and following radiotherapy for head and neck cancer were evaluated (experimental group) and compared with the same properties in a control group of 21 subjects free of cancer. Salivary flow was evaluated by measuring the time necessary, in seconds, for the output of $2 \mathrm{ml}$ of stimulated saliva; and the buffering capacity changes were determined using a simple colorimetric method. Total salivary protein concentration was determined by the Bradford ${ }^{4}$ method. $^{\circ}$ Amylase activity was measured by reducing sugars released from a soluble starch substrate, quantified by the dinitrosalicylic method. The electrophoretic profile was evaluated in polyacrylamid gel (12\% SDS-PAGE) using samples of $5 \mu \mathrm{g}$ of salivary protein. A statistically significant reduction $(\mathrm{p}<0.01)$ of the salivary flow was observed, (162.47 $\mathrm{s} \pm 28.30$ before and $568.71 \mathrm{~s} \pm 79.75$ after irradiation), as well as a reduction in the salivary buffering capacity (pH $5.45 \pm 0.14$ before and $\mathrm{pH} 4.40 \pm 0.15$ after irradiation). No statistically significant alteration was observed in total salivary protein concentration. A statistically significant reduction $(\mathrm{p}<0.01)$ of salivary $\alpha$-amylase activity ( $856.6 \mathrm{ng} / \mathrm{mg} \pm 88.0$ before and $567.0 \mathrm{ng} / \mathrm{mg} \pm 120.6$ after irradiation) was observed. Electrophoretic profile differences in salivary protein bands were also observed after radiotherapy, mainly in the range of molecular weight of 72,000 to 55,000 Daltons. Clinically, patients presenting xerostomia induced by radiotherapy presented an increase in oral tissue injury.
\end{abstract}

DESCRIPTORS: Radiotherapy; Saliva; Xerostomia; Biochemistry.

\begin{abstract}
RESUMO: Foram avaliados alguns aspectos clínicos e algumas propriedades bioquímicas salivares de 21 pacientes, antes e após o tratamento radioterápico para câncer de cabeça e pescoço (grupo experimental) e de 21 pacientes sem câncer (grupo controle). O fluxo salivar foi avaliado pelo tempo necessário (segundos) para produção estimulada de $2 \mathrm{ml}$ de saliva e a capacidade tamponante determinada frente à utilização de um método colorimétrico simples. A concentração de proteína total salivar foi determinada pelo método de Bradford ${ }^{4}$. A atividade da amilase foi mensurada através dos açúcares redutores liberados e quantificados pelo método do ácido dinitrossalicílico utilizando a glicose como substrato. O perfil eletroforético foi avaliado em gel de poliacrilamida (SDS-PAGE 12\%) para amostras salivares contendo $5 \mu \mathrm{g}$ de proteína. Foi observada, no grupo experimental, redução estatisticamente significativa ( $<<0,01)$ para o fluxo salivar $(162,47 \mathrm{~s} \pm 28,30$ antes e $568,71 \mathrm{~s} \pm 79,75$ após) e para a capacidade

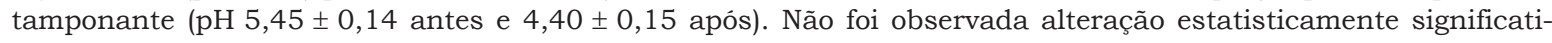
va na concentração de proteína. A atividade específica da $\alpha$-amilase foi significativamente diminuída $(p<0,01)$ (856,6 $\mathrm{ng} / \mathrm{mg} \pm 88,0$ antes e $567,0 \mathrm{ng} / \mathrm{mg} \pm 120,6$ após). No perfil eletroforético, foram observadas diferenças nas bandas protéicas, principalmente na faixa de peso molecular de 72.000 a $55.000 \mathrm{Da}$. Clinicamente, os pacientes com xerostomia induzida pela radioterapia apresentaram aumento de lesões na mucosa.
\end{abstract}

DESCRITORES: Radioterapia; Saliva; Xerostomia; Bioquimica.

\section{INTRODUCTION}

Studies related to physiology, biochemistry and microbial ecology of the oral cavity are essential for progress in the field of oral health.

There are many causes for the alteration of the salivary flow rate, mainly due to therapeutic interventions, Sjögren's syndrome, head, neck and total body irradiation, diabetes, alcohol consumption tobacco use; idiopathies and other systemic conditions $^{2,3,7,11,12,13,18}$. Radiotherapy aimed at the destruction of tumor cells is a significant form of

\footnotetext{
* Master in Oral Rehabilitation, School of Dentistry of Ribeirão Preto; **Biologist, Department of Physics and Chemistry, School of Pharmaceutical Sciences of Ribeirão Preto; ${ }^{* *}$ Head Professor, Department of Physics and Chemistry, School of Pharmaceutical Sciences of Ribeirão Preto - University of São Paulo.
} 
Pontes CB, Polizello ACM, Spadaro ACC. Clinical and biochemical evaluation of the saliva of patiens with xerostomia induced by radiotherapy. Braz Oral Res 2004;18(1):69-74.

head and neck oncological treatment. It also has effects on normal tissues. In the field of oral and maxillofacial oncology, damage caused by radiation in the oral mucosa, salivary glands and bone has a very significant clinical effect.

Along with alterations of the signs and symptoms present in these patients due to radiotherapy, biochemical alterations occurred in their saliva ${ }^{1,9,16}$

The buffer capacity evaluation has great importance to oral health. The early diagnosis of patients with low buffer capacity prevents damage to teeth and oral tissues ${ }^{14}$.

Funegard et al. ${ }^{5}$ (1994) studied the composition of saliva prior to, during, and after radiotherapy in 16 patients treated for head and neck cancer. During the whole treatment, the volume of saliva decreased by $40 \%$. After 18 months, the average volume reached $72 \%$ of the initial value observed. The concentrations of total protein, salivary peroxidase and IgA showed small increases that persisted for up to six months after the end of the treatment.

The purpose of this study was to evaluate the biochemical properties of the saliva (salivary flow rate, buffering capacity, amylase activity, total protein content and electrophoretic profile), in two groups of subjects (experimental patients and cancer-free controls), correlating changes observed with their clinical evaluation.

\section{MATERIAL AND METHODS Subjects}

The participants of this research were divided into two groups of 21 subjects each. The first group was composed of cancer patients submitted to irradiation treatment of the head and neck at the Radiotherapy Clinic of the Clinical Hospital of Ribeirão Preto (HCFMRP-USP), leading to the development of xerostomia. The second group was composed of 21 patients of the School of Dentistry of Ribeirão Preto (FORP-USP), used as controls, which did not present head or neck cancer. Age, sex, race, class or social groups were not taken into account. All patients showed good general health and were not taking any medication capable of changing the production of saliva. These rules for the selection of patients constituted the protocol of the study. All subjects were submitted to saliva collection performed by the researchers, after reading and signing a written authorization approved by the Ethics and Research Committee of the School of Dentistry of Ribeirão Preto.

\section{Collection of the saliva}

Two $\mathrm{ml}$ of saliva were collected after the patients had chewed on a piece of Parafilm (3M, Chicago, USA). The saliva of patients of group I was collected prior to and after radiotherapy. The collection of saliva after the treatment occurred as soon as the last section of radiotherapy was finished. Most of the patients received approximately 35 daily doses that varied between 50 to 70 cGy. The first collection was performed for individual control, rendering it possible to compare the responses of each patient of group I (with cancer) before and after irradiation, as well as with those of the patients of group II (without cancer). The time of production of this amount of saliva was registered and used to determine the salivary flow rate. All patients were instructed not to eat, drink or smoke during the one hour preceding the collections. The samples of saliva were centrifuged at $16,000 \mathrm{~g}$ at $4^{\circ} \mathrm{C}$ for 10 minutes and aliquot quantities were stored at $-70^{\circ} \mathrm{C}$ until biochemical analysis took place ${ }^{9,16}$.

\section{Biochemical properties Buffering capacity}

For the evaluation of the salivary buffering capacity, a simple colorimetric method was used, according to Spadaro et al. ${ }^{14}$ (1998).

The colorometric determination of the $\mathrm{pH}$ of the saliva was observed with $0.5 \mathrm{ml}$ of the sample in a small tube of transparent glass with $0.5 \mathrm{ml}$ of hydrochloric acid $12 \mathrm{mmol} / 1$, analyzed with $0.05 \%$ of bromocresol green. The color obtained in the tube was compared with colors previously developed on a computer scale.

\section{Protein determination}

The total protein content of the centrifuged saliva samples (5 $\mu \mathrm{g} /$ sample) was determined by Bradford $^{4}$ (1976) using bovine serum albumin (Sigma CO., St. Louis, USA) as standard.

\section{Salivary amylase activity}

The activity of salivary amylase was measured at $25^{\circ} \mathrm{C}$, according to van Staden, Mulaudzi ${ }^{17}$ (2000). In this method, the saliva was conveniently diluted (250 times) in $0.05 \mathrm{~mol} / 1$ phosphate buffer, pH 6.9 (Merck KGaA, Darmstadt, Germany). The substrate used was soluble starch (Merck KGaA, Darmstadt, Germany), and the reducing sugars liberated by the enzymatic action were quantified by the dinitrosalicylic acid method ${ }^{10}$, using glucose to plot the standard curve. 
Pontes CB, Polizello ACM, Spadaro ACC. Clinical and biochemical evaluation of the saliva of patiens with xerostomia induced by radiotherapy. Braz Oral Res 2004;18(1):69-74.

\section{Electrophoresis}

Electrophoresis using $12 \%$ polyacrylamide gels with sodium dodecyl sulfate (SDS) as support (SDS-Page) were prepared according to Laemmli ${ }^{8}$ (1970).

The stacking and separating gels contained 5 and $12 \%$ acrylamide, respectively. The gels were prepared with dimensions of $100 \times 80 \times 0.75 \mathrm{~mm}$. Electrophoresis was carried out until the tracking dye (bromophenol blue) reached the bottom of the gel (approximately $2.5 \mathrm{~h}$ at $10 \mathrm{~mA}$ ).

The gels were stained with $0.25 \%(\mathrm{w} / \mathrm{v}) \mathrm{Co}-$ massie Brilliant Blue G (Vetec, Duque de Caxias, Brazil) in 50\% methanol (w/v) and $7 \%(\mathrm{w} / \mathrm{v})$ acetic acid for 1 hour and destained with a bleaching solution (Merck KGaA, Dermstadt, Germany) [5\% $(\mathrm{v} / \mathrm{v})$ methanol and $7.5 \%(\mathrm{v} / \mathrm{v})$ acetic acid].

\section{Clinical evaluation}

The symptoms were evaluated according to the patient's complaints. The information was written down to have the list of the main symptoms in patients with head and neck cancer submitted to radiotherapy.

\section{Statistical analysis}

Statistical analysis of the results was performed with the Student's $t$-test and the U test of Mann-Whitney.

\section{RESULTS}

Graph 1 shows the main symptoms of patients with xerostomia induced by radiotherapy. Among them, loss of taste was most frequently observed, even in patients with little or no xerostomia.

Table 1 expresses average values ( \pm s.d.) found

TABLE 1 - Average values ( \pm standard deviation) of the flow rate and buffering capacity of the saliva of the experimental (group I) and control study (group II) groups.

\begin{tabular}{c|c|c|c|c}
\hline \hline \multirow{2}{*}{ Before } & \multicolumn{2}{|c|}{ Salivary flow rate (s) } & \multicolumn{2}{c}{ Buffer capacity (pH) } \\
\cline { 2 - 5 } & Group I & Group II & Group I & Group II \\
\cline { 2 - 5 } & $\begin{array}{c}162.50 \\
( \pm 28.31)\end{array}$ & $\begin{array}{c}223.50 \\
\left( \pm 33.05^{* *}\right)\end{array}$ & $\begin{array}{c}5.45 \\
( \pm 0.14)\end{array}$ & $\begin{array}{c}5.02 \\
\left( \pm 0.15^{* *}\right)\end{array}$ \\
\hline \multirow{2}{*}{ After } & $\begin{array}{c}568.70 \\
\left( \pm 79.75^{*}\right)\end{array}$ & - & $\begin{array}{c}4.40 \\
\left( \pm 0.15^{*}\right)\end{array}$ & - \\
\hline \hline
\end{tabular}

$\mathrm{s}=$ time necessary to obtain a flow of $2 \mathrm{ml}$ of saliva (seconds). *Significantly different from the initial data of group I $(\mathrm{p}<0.01)$.

**Significantly different from the final data of group I $(\mathrm{p}<0.01)$. for the salivary flow rate and buffering capacity of the experimental group (group I), before and after radiotherapy, as well as of the control group (group II).

A statistically significant reduction $(\mathrm{p}<0.01)$ of the salivary flow rate and buffering capacity was observed in patients of the experimental group after radiotherapy.

Table 2 shows the average values ( \pm s.d.) of specific activity of enzyme ( $\alpha$-amylase) found for the experimental group before and after radiotherapy (group I), as well as for the control group (group II).

The electrophoregrams of the patient's saliva, when compared before and after radiotherapy (group I), showed small differences in some regions of relative molecular mass (RM). On the other

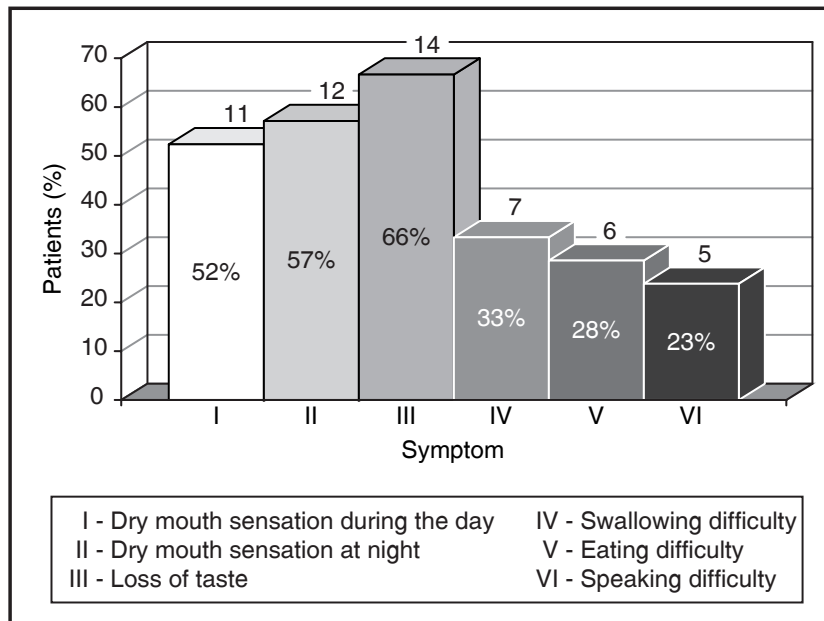

GRAPH 1 - Main symptoms in patients submitted to radiotherapy.

TABLE 2 - Average values, with their respective standard deviations of the specific activity of amylase of the experimental group (group I) before and after radiotherapy, as well as of the control group (group II).

\begin{tabular}{l|c|c}
\hline \hline \multirow{2}{*}{} & \multicolumn{2}{|c}{$\begin{array}{c}\text { Specific activity of amylase (ng glucose } \\
\text { liberated } / \mathrm{mg} \text { protein) }\end{array}$} \\
\cline { 2 - 3 } & Group I $(\mathrm{n}=17)$ & Group II $(\mathrm{n}=20)$ \\
\hline Before & $856.6 \pm 88.0$ & $1,068.0 \pm 183.3^{* *}$ \\
\hline After & $567.0 \pm 120.6^{*}$ & - \\
\hline \hline
\end{tabular}

*Significantly different from the initial data of group I $(p<0.01)$. **Significantly different from the final data of group I $(p<0.05)$. There were no differences found between the experimental and control groups. 
Pontes CB, Polizello ACM, Spadaro ACC. Clinical and biochemical evaluation of the saliva of patiens with xerostomia induced by radiotherapy. Braz Oral Res 2004;18(1):69-74.

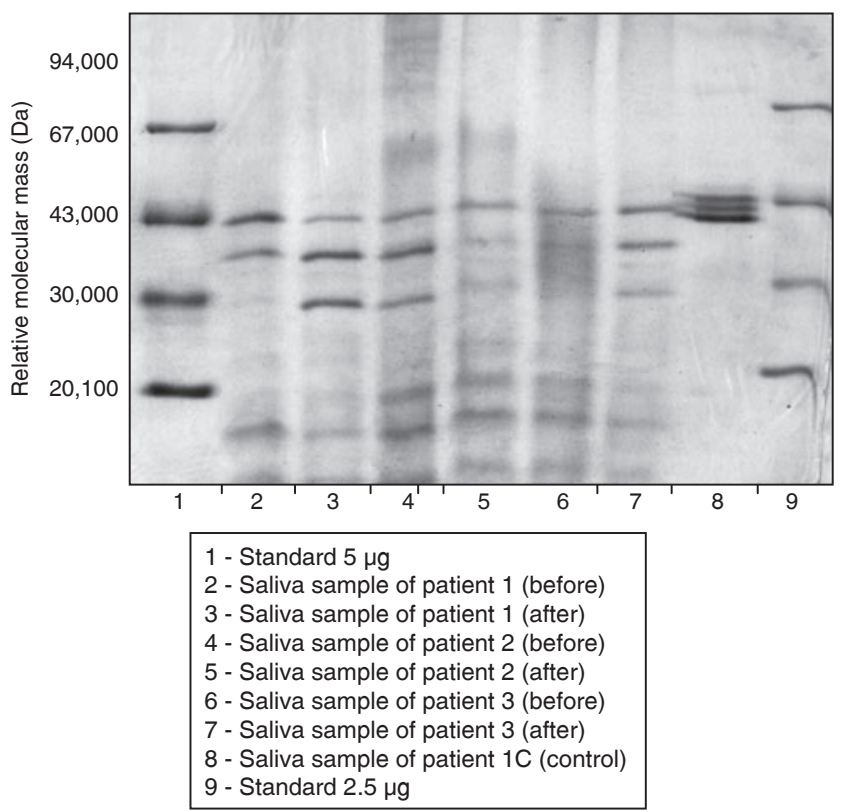

FIGURE 1 - Electrophoregrams of some patient's saliva

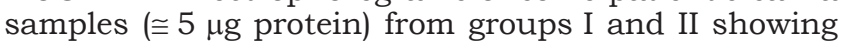
alterations between them.

hand, an expressive difference was observed when comparing patients of groups I and II.

Figure 1 illustrates an example of electrophoretic records which show alterations in RM between bands of molecular weights 72,000 to 55,000 Daltons between groups I and II.

\section{DISCUSSION}

A review of literature shows that many clinical and biochemical alterations in the oral cavity and in the saliva can occur in patients exposed to radiotherapy ${ }^{2,15}$.

In this work we noted that in about 10-15 stages of the radiotherapy treatment (second week), patients started to show the first signs and symptoms of alterations caused by radiation. Among the main symptoms (Graph 1) were: loss of taste, xerostomia during the day and at night, burning sensation, difficulty in swallowing, talking and eating. Among the main signals observed were: mucositis, rampant caries, parched skin and flushing in the irradiated area.

All participants of the experimental group of this study showed reduction of the salivary flow rate. Some reported severe alterations relating to discomfort and pain, others showed less of the latter.

Regarding the data collected from patients of the experimental group, both for salivary flow rate and for buffering capacity before and after radiotherapy, a significant difference at $(p<0.01)$ occurred. This confirms data found in the literature ${ }^{2}$, and in our clinical observations in which patient's saliva after treatment was scarce and considerably more viscous, leading to oral discomfort.

The comparison between the salivary flow rate and buffering capacity of the control group with the same parameters of data of the experimental patients prior to treatment did not show a significant difference $(\mathrm{p}<0.05)$.

The same result did not occur when a statistical comparison was made between salivary flow rate and the buffering capacity of the data obtained at the end of the treatment of the experimental group, and the data of the control group. In this case, there was a significant difference $(\mathrm{p}<0.01)$.

This shows that reduction of the salivary flow rate and of the buffering capacity are directly linked to radiotherapy treatment and not to the presence of cancer. In other words, a patient with head and neck cancer (HNC) has, prior to radiotherapy, a normal salivary flow rate and buffering capacity, just like patients without HNC.

These results are in agreement with those of several papers found in the literature ${ }^{6,15,16}$.

The statistical comparison between the total concentration of salivary protein before the radiation treatment of patients of the experimental group with data obtained after the treatment showed no significant differences ( $p>0.05)$. Also, the same comparison between data from the control group with the initial or final data of the experimental group showed no significant differences $(\mathrm{p}>0.05)$.

Although not noted here, a statistically significant alteration of the concentration of total protein was described in the work of Funegard et al. ${ }^{5}$ (1994), where a significant increase of the total protein concentration was reported. On the other hand, a reduction of the specific activity of the $\alpha$-amylase was noted, indicating that radiation acts specifically on some proteins.

Salivary amylase has high activity: dilutions to evaluate its activity became necessary. It is also resistant to some proteolytic enzymes produced by microorganisms of the oral cavity. Therefore, the evaluation of this enzyme can faithfully represent biochemical alterations that occurred due to the radiation treatment of group I patients.

The statistical analysis of the specific activity of amylase in the data obtained before and after 
Pontes CB, Polizello ACM, Spadaro ACC. Clinical and biochemical evaluation of the saliva of patiens with xerostomia induced by radiotherapy. Braz Oral Res 2004;18(1):69-74.

the treatment showed that there was a significant difference $(p<0.01)$.

There was no significant difference $(\mathrm{p}<0.05)$ between data from control and experimental groups for the specific activity of this enzyme prior to radiotherapy, but there was a significant difference $(p<0.05)$ for the tests performed between data of the control group and data from the experimental group after treatment. This suggests that the specific activity of $\alpha$-amylase, like those of the salivary flow rate and buffering capacity, were modified during radiotherapy. This is due to the fact that irradiation destroys glandular tissue, mostly serous acini, causing changes in the quantity and quality of the saliva produced by patients after going through the head and neck radiotherapy treatment.

With our results it becomes possible to affirm that neither the radiotherapy treatment, nor the presence of cancer had an influence on the total concentration of salivary proteins. However, this does not mean that specific activity of a given enzyme remains unchanged after the treatment, as noticed for $\alpha$-amylase.

This specific difference happens because of the many components of total saliva that are produced in several glands ${ }^{13}$.

The observation of electrophoregrams of total saliva samples of patients with cancer showed notable differences, in some areas of relative molecular mass, comparing to the control group. This variation was verified in the relative molecular mass region of 72,000 to 55,000 of the gel under

\section{REFERENCES}

1. Almstahl A, Wikstrom M, Groenink J. Lactoferrin, amylase and mucin MUC5B and their relation to the oral microflora in hyposalivation of different origins. Oral Microbiol Immunol 2001;16:345-52.

2. Andrews N, Griffiths C. Dental complications of head and neck radiotherapy: Part 1. Aust Dent J 2001;46:88-94.

3. Blom M, Kopp S, Lundeberg T. Prognostic value of the pilocarpine test to identify patients who may obtain longterm relief from xerostomia by acupuncture treatment. Arch Otolaryngol Head and Neck Surg 1999;125:561-6.

4. Bradford MM. A rapid and sensitive method for the quantitation of microgram quantities of protein utilizing the principle of protein-dye binding. Anal Biochem 1976;72:248-54.

5. Funegard U, Franzen L, Ericson T, Henriksson R. Parotid saliva composition during and after irradiation of head and neck cancer. Eur J Cancer B Oral Oncol 1994;30B:230-3.

6. Greer JE, Eltorky M, Robbins KT. A feasibility study of salivary gland autograft transplantation for xerostomia. our experimental conditions, and rendered it possible to observe a marked difference in the migration of protein bands, in the control group, in $70 \%$ of the cases studied. The control group showed a set of bands that correspond to the cited bands of RM (72,000 to 55,000 Daltons), while in $70 \%$ of the electrophoregrams of patients before or after radiotherapy it is possible to observe a marked decrease of these protein bands at the same relative molecular mass band considered. This leads us to infer that the proteins that migrate to this region can be undergoing a partial proteolytic process, causing a decrease in their molecular mass or changes in their synthesis or post-translational changes.

\section{CONCLUSIONS}

Under the experimental conditions of this study we shall conclude that patients submitted to radiotherapy to treat head and neck cancer present a significant reduction of salivary flow rate, buffering capacity and protein electrophoretic pattern in relation to healthy individuals.

\section{ACKNOWLEDGMENTS}

To the coordinator and supervisor of the technical and administrative activities of the Department of Radiotherapy from the Clinical Hospital (HCFMRP-USP), Dr. Thomaz Ghilarde Netto, for the authorization to work in the clinic of radiotherapy and carry out this work. To the CAPES for the financial support.

Head Neck 2000;22:241-6.

7. Kolanjiappan K, Ramachandran CR, Manoharan S. Biochemical changes in tumor tissues of oral cancer patients. Clin Biochem 2003;36:61-5.

8. Laemmli UK. Cleavage of structural proteins during the assembly of the head of bacteriophage T4. Nature 1970;227:680-5.

9. Lenander-Lumikari M, Ihalin R, Lähteenoja H. Changes in whole saliva in patients with coeliac disease. Arch Oral Biol 2000;45:347-54.

10. Miller GL. Use of dinitrosalicylic acid reagent for determination of reducing sugar. Anal Chem 1959;31:426-8.

11. Momm F, Muller M, Tsekos A, Guttenberger R. Xerostomia after radiotherapy. More effective treatment by a mucincontaining spray? HNO 2001;49:831-6.

12. Pontes CB, Freitas KM, Paranhos HFO, Spadaro ACC. Reabilitação oral com prótese total em paciente curado de câncer bucal, tratado com cirurgia e radioterapia. PCL 2002;4:402-6.

13. Ship JA. Diagnosing, managing and preventing salivary 
Pontes CB, Polizello ACM, Spadaro ACC. Clinical and biochemical evaluation of the saliva of patiens with xerostomia induced by radiotherapy. Braz Oral Res 2004;18(1):69-74.

gland disorders. Oral Dis 2002;8:77-89.

14. Spadaro ACC, Caldeira TH, Rocha CB, Polizello ACM, Mestriner Jr W. Método para avaliação clínica da capacidade tamponante salivar. Rev Odontol Univ São Paulo 1998;12:247-51.

15. Spolidorio DMP, Spolidorio LC, Barbeiro RH, Höfling JF, Bernardo WLC, Pavan S. Avaliação quantitativa de Streptococcus do grupo mutans e Candida $s p$. e fatores salivares na cavidade bucal de pacientes submetidos à radioterapia. Pesqui Odontol Bras 2001;15:354-8.
16. Sreebny LM, Zhu W, Schwartz SS, Meek AG. The preparation of an autologous saliva for use with patients undergoing therapeutic radiation for head and neck cancer. $\mathrm{J}$ Oral Maxillofac Surg 1995;53:131-9.

17. van Staden JF, Mulaudzi LV. Flow injection spectrophotometric assay of $\alpha$-amylase activity. Anal Chem Acta 2000;421:19-25.

18. Wingo PA, Tong T, Bolden S. Cancer statistics, 1995. CA Cancer J Clin 1995;45:8-30. Erratum in: CA Cancer J Clin 1995;45:127-8.

Received for publication on June 02, 2003 Sent for alterations on Nov 25, 2003 Accepted for publication on Feb 10, 2004 